This item was submitted to Loughborough's Research Repository by the author.

Items in Figshare are protected by copyright, with all rights reserved, unless otherwise indicated.

\title{
Developing mathematics teaching through collaborative inquiry
}

PLEASE CITE THE PUBLISHED VERSION

http://www.routledge.com/

PUBLISHER

(c) Routledge, Taylor \& Francis

VERSION

AM (Accepted Manuscript)

LICENCE

CC BY-NC-ND 4.0

REPOSITORY RECORD

Jaworski, Barbara. 2019. "Developing Mathematics Teaching Through Collaborative Inquiry”. figshare. https://hdl.handle.net/2134/8829. 
This item was submitted to Loughborough's Institutional Repository (https://dspace.lboro.ac.uk/) by the author and is made available under the following Creative Commons Licence conditions.

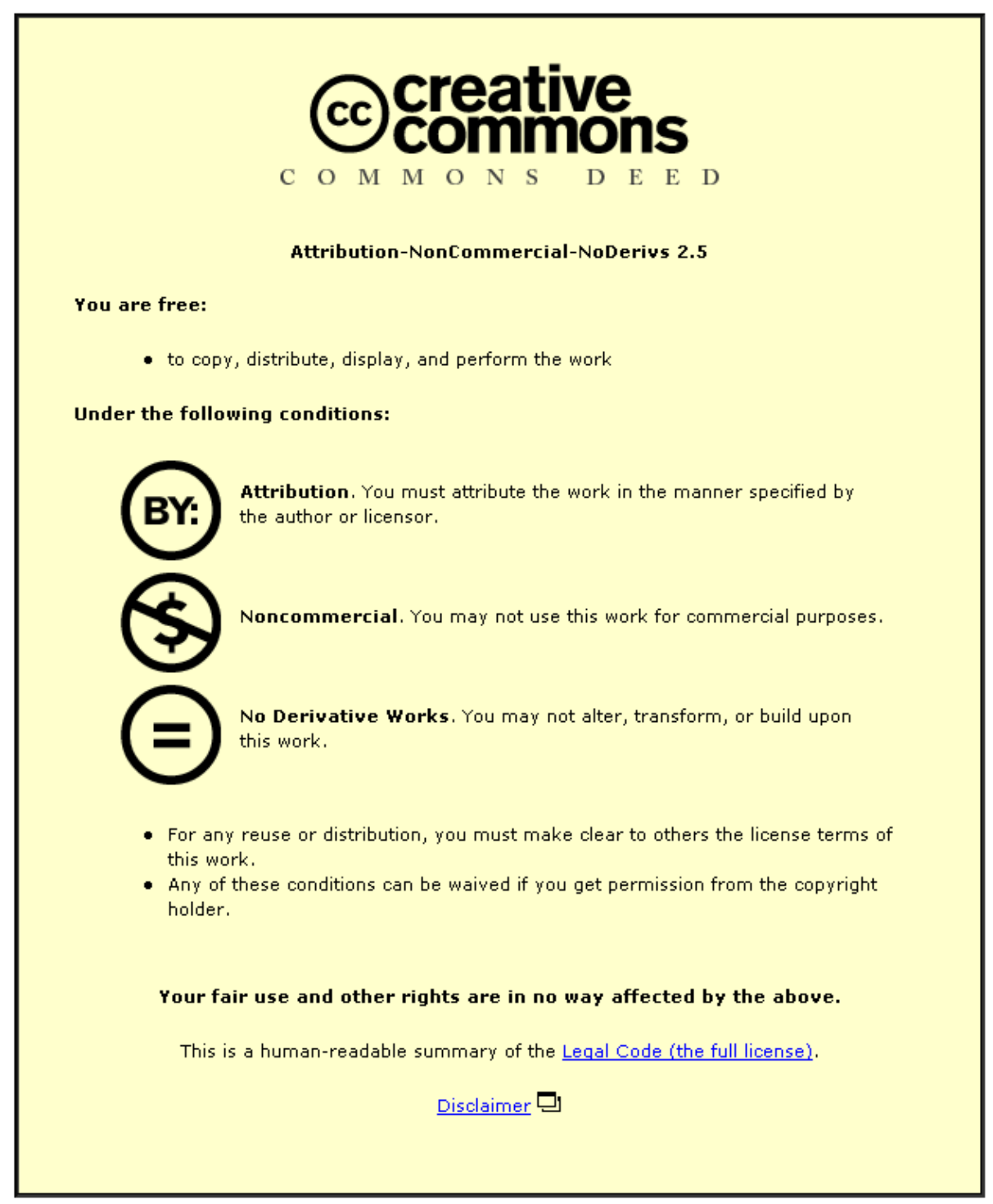

For the full text of this licence, please go to: http://creativecommons.org/licenses/by-nc-nd/2.5/ 


\title{
DEVELOPING MATHEMATICS TEACHING
}

\section{THROUGH COLLABORATIVE INQUIRY}

\author{
Barbara Jaworski \\ Loughborough University, UK and University of Agder, Norway
}

\section{INTRODUCTION}

This chapter addresses theory and practice in a developmental research project in which mathematics teachers and didacticians worked together to develop mathematics teaching. The mathematics teachers were from 8 schools in Norway ranging from lower primary to upper secondary. Didacticians were academics in mathematics education in a university. Both were practitioners in their own areas of practice and in the project both were researchers. The project sought to know more about how mathematics teaching can develop to enhance learning experiences for students in mathematics classrooms. It was called Learning Communities in Mathematics, $\mathrm{LCM}^{1}$, and involved teachers and didacticians in inquiry communities exploring together and evaluating possibilities for classrooms and students (Jaworski, Fuglestad, Bjuland, Breiteig, Goodchild \& Grevholm, 2007). Over a period of four years, including three phases of school-related activity each of one school year, 14 didacticians (including 5 doctoral students) and 35 teachers were involved in the project.

The theoretical root of the project was the notion of inquiry community, of mathematics teachers and didacticians exploring together and evaluating 
possibilities for classrooms and students. The project was conceptualized around inquiry in three levels or layers:

1. in classroom mathematics,

2. in planning/designing for the mathematics classroom,

3. in researching the developmental process.

Inquiry was seen both as a tool in promoting mathematical thinking and as central to both development and research. We see the three elements as deeply related to each other in a sense of nested layers as represented in Figure 1 below. Research (outer layer) into the activity of the two inner layers both charts that activity and its development while simultaneously contributing to that development (Jaworski, 2003).

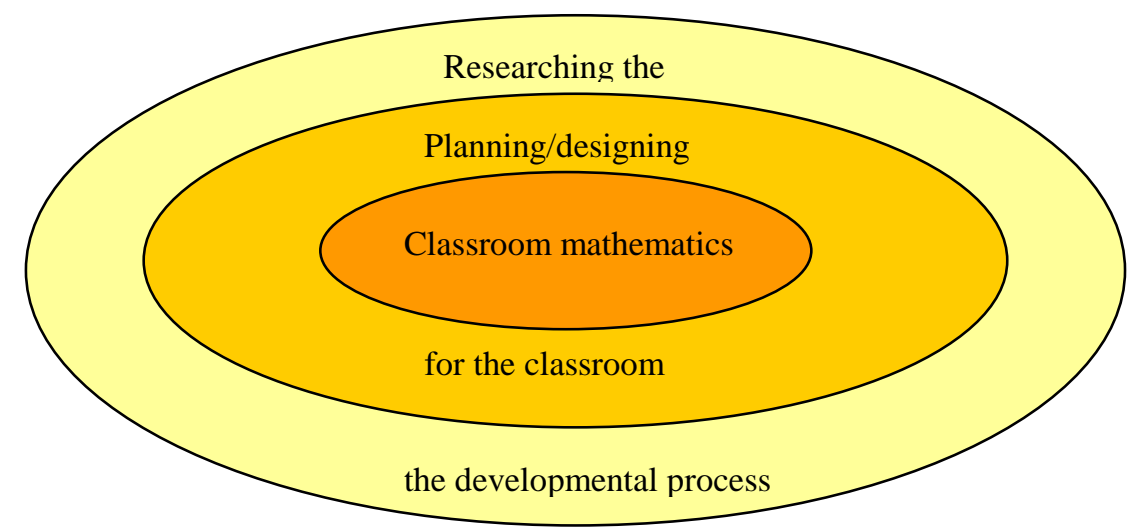

Figure 1 - Nested layers of inquiry in the LCM Project

\section{LEARNING THROUGH PARTICIPATION AND THE POSITION OF TEACHING}

Community of inquiry draws on Lave and Wenger's (1991) theory of community of practice, and Wenger's (1998) construct of belonging to a community of 
practice. Community refers to a group of people identifiable by who they are in terms of how they relate to each other, their common activities and ways of thinking, beliefs and values. According to Wenger,

The concept of practice connotes doing, but not just doing in and of itself. It is doing in a historical and social context that gives structure and meaning to what we do. In this sense practice is always social practice (Wenger, 1998, p.47).

Wenger suggests that belonging to, participating in, or having identity in a community of practice involves engagement, imagination and alignment. We engage with ideas through communicative practice, develop those ideas through exercising imagination and align ourselves "with respect to a broad and rich picture of the world" (p. 218). Align, literally 'to line up with', indicates that we are positioned according to, or in line with the practices and activities in the communities in which we participate.

The terms participation, belonging, engagement and alignment all point towards the situatedness of doing and being and the growth of knowledge in practice. In LCM, for example, teachers and didacticians engage in practices in workshops and school settings and align themselves with existing or emerging practices related to the particular setting. Imagination contributes to the emergence of new practices. Interactivity and relationships between people within a community establish norms of practice and ways of being in the community. Identities are formed through situated engagement; individual or group identity relates to ways of being in communities to which we belong. What people do, what they know and their concomitant growth of knowledge relate to their 
interactivity in social settings. For example, in LCM, which had teacher teams in 8 schools, any individual teacher or didactician developed identity related to their participation in the project particularly, but constituted relative to the many other communities of which the individual was part.

Thus within a theoretical perspective of community of practice, participants are seen as situated with respect to their practice and learning through participation in practice (Rogoff, Matusov and White, 1996). Since participants are teachers (and, to an extent, didacticians are also teachers) we need to consider how the roles of teachers can be seen to fit within such a community learning model. Therefore we ask, if learning is participating in a community of practice, what is teaching? If a teacher is supposed to enable others to learn, how can a teacher enable learning through participation? What can this mean?

Jean Lave writes,

People who have attended school for many years may well assume that teaching is necessary if learning is to occur. Here I take the view that teaching is neither necessary nor sufficient to produce learning, and that the socio-cultural categories that divide teachers from learners in schools mystify the crucial ways in which learning is fundamental to participation and all participants in social practice. (Lave, 1996, p. 157)

Social practice theory is illuminative in offering a means of characterizing and analyzing learning: for example, teachers' learning of mathematics teaching, or pupils' learning of mathematics. However, the frame is unhelpful in characterizing or analyzing mathematics teaching, i.e., enabling others to learn. 
Indeed, according to Lave, "teaching is neither necessary nor sufficient to produce learning".

Children learn through participation in many contexts, both inside and outside the classroom. Where mathematics is concerned, however, many concepts are not available to children through everyday activity. Mathematical concepts are scientific concepts (Vygotsky,1962) and, according to Schmittau (2003, p. 226). "require pedagogical mediation for their appropriation". Pedagogical mediation involves both the creation of a classroom environment in which learners can engage with mathematics and encounter norms of mathematical practice, and provision of scaffolding related to zones of proximal development (Bruner, 1985). Such provision seems to sit firmly within the role of a teacher of mathematics.

So, how do we interpret the term "teaching"? What exactly is taken to be the role of a teacher? To see mathematics learning as through participation in a community of mathematical practice, we have to consider how such a community is created. For example, we might see mathematical practice, "doing mathematics", to involves elements of mathematical tasks, mathematical thinking, mathematical reasoning, generalisation, abstraction and proof. Where can such elements be found or how can they be created in classroom situations so that pupils can engage with them? These questions provide a possible way ahead: if we see learning mathematics in classrooms as participation in the social practice of the classroom we might see teaching mathematics similarly as participation in the social practice of creating opportunity for mathematics 
learning. In both cases, inquiry can be seen as an important tool in the process: inquiry promotes questions into mathematics or into mathematics teaching which, concomitantly, encourage deep levels of participation and reflection.

Lave writes further

... if teachers teach in order to effect learning, the only way to discover whether they are having effects and if so what those are, is to explore whether, and if so how, there are changes in the participation of learners learning in their various communities of practice. If we intend to be thorough, and we presume teaching has some impact on learners, then such research would include the effects of teaching on teachers as learners as well (1996, p. 158).

If we see teaching as a practice in established settings, aimed at promoting learning of mathematics, then we might simultaneously see learning of teaching through participation in teaching. This suggests a developmental model for teaching. However, research of Brown and Mclntyre (1993) suggests that such a model is not obvious as a part of normal teaching practice. In their study of teaching in natural settings of classrooms over a substantial time period, Brown and McIntyre saw the teaching-learning situation settling down to norms that they referred to as "normal desirable states". A state was desirable in that teacher and pupils found ways of working together that were comfortable to both. In Wenger's terms we might suggest that alignment over time leads to creation of 'normal desirable states' between teachers and students. A question then arises as to what outcomes the normal desirable state is achieving in 
terms of students' successful learning of mathematics and whether those involved ask this question of their practice. Recent results from TIMSS and PISA tests in several western countries, including the UK and Norway (e.g. OECD, 2004; Mullis, Martin, Gonzalez, \& Chrostowski, 2004), suggest students are not achieving as well as those in other parts of the world. It seems worth inquiring into classroom norms that result in such outcomes.

Returning to Lave and notions of "teaching as a practice" in which the knowledge of teaching is in the practice of teaching, it is possible to study aspects of this practice and provide deep accounts of both the practice and the knowledge within. The unit of analysis here is practice, and the focus of research is on an arena or situation which allows a study of practice - for example a whole school or one classroom. Such a study might try to capture learning, or growth of knowledge, within teaching - i.e., teachers learning about teaching as part of their practice of teaching. This begs the question about how learning about teaching links to pupils' learning of mathematics.

The design of our study is intended to provide this link. We provided for interactivity of teachers and didacticians in workshop and school situations in which we explored possibilities for enabling pupils to inquire into and hence learn mathematics. Fundamental to this inquiry process is that "belonging" to the project community extends Wenger's "alignment" to "critical alignment" (Jaworski, 2006) through which we (teachers and didacticians) question overtly both established practices and the new approaches we design within the project. The concept of critical alignment recognizes the necessity of aligning 
with the norms of practice in order to function within a community of practice and, as well as, or as part of this recognition, questions the ways of doing and being within the practice. In LCM, this questioning looked fundamentally at what the practice achieves or fails to achieve in terms of providing opportunity for students' learning of mathematics and considered what might offer enhanced learning opportunities. This involved questioning current practice while engaging in practice - what is possible and how - what do we want to try to achieve and what does it look like in practice? What is emergent from such engagement and questioning? We started by using "inquiry" as a tool for learning and working towards inquiry as a stance, as a way-of-being-in-practice (Cochran Smith and Lytle, 1999; Jaworski, 2004).

\section{INQUIRY AS A TOOL FOR LEARNING}

Within the LCM project operationalization of the ideas above has involved grappling with notions of inquiry in all three layers both separately and together. Project design had suggested that the project would be interpreted through joint activity between teachers and didacticians in workshops at the university and innovation in schools. The former should allow us to explore ideas and discuss possibilities outside the immediacy of school settings; the latter would bring ideas into the practice arena with consideration of all the interpersonal and institutional factors that are part of school life. In both cases we came to regard our interpretation of theory in practice as comprising a design/inquiry cycle of plan, act, reflect, feedback, which becomes a research cycle when we also observe and analyse; see Figure 2. The left hand part of the figure constitutes 
the developmental cycle, plan, act, reflect, feedback, while the right hand side constitutes the research cycle, plan, observe, analyse, feedback.

Plan

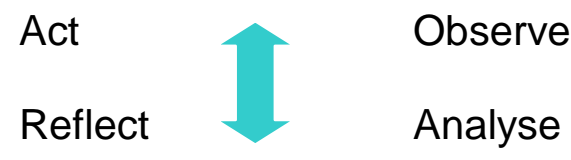

. . Feedback

Figure 2: A research cycle in developmental design

In the case of design of workshops, an early decision was taken by didacticians that it could be valuable for teachers and didacticians to do mathematics together in workshops as a basis for thinking about issues in learning and teaching. Thus, in advance of each workshop (we had sixteen workshops during the three phases of the project) didacticians planned mathematical tasks with which all participants would engage in the workshop setting. Immediately after each workshop, the didactician team reflected on the workshop activity and outcomes and these reflections fed back to future planning and task design. For didacticians, these actions constituted the developmental part of the activity. In addition, observation took place involving data capture in audio or video form from all activity - planning, workshop and reflection - with subsequent analysis, resulting in a research formulation from the activity. Deliberation on possible tasks, the tasks that were designed, the overt observation, reflection and analysis can all be regarded as inquiry tools. 
In the case of activity in schools, teachers, singly or as a team, designed tasks for their classroom(s). A range of schools, from lower primary to upper secondary, and a larger overall number of people, meant that design activity of teachers in schools was much more diverse than that of didacticians in planning workshops. Often, school design actually started in a workshop, either with a workshop task which would be modified for use in a classroom, or with group activity in the workshop, often with teachers from several schools, planning a lesson sequence. In the school setting, the tasks had to be re-formulated appropriately for use in the classroom; lesson sequences had to be adjusted to fit particular school circumstances. Thus, school planning activity might involve a group of teachers or just one teacher in formulating tasks that could fit forms of activity in the particular school environment. We can see here critical alignment in practice as teachers used ideas they had generated in the workshop setting to offer opportunity to pupils, while at the same time adjusting innovatory ideas to school norms and traditions. The workshop tasks, lesson sequences, deliberations within or between teachers, and adjustments for the school setting can all be regarded as inquiry tools. In the research part of the school cycle, teachers through observation and reflection fed back to future activity and presented outcomes in workshops; didacticians collected video data from classrooms for future analysis according to a range of research questions. A discussion of the complexities of research in the project is beyond the scope of this chapter.

The two paragraphs above describe more overt forms of activity in the project. Less overt in some ways are the involvements of teachers in workshop 
planning and of didacticians in school planning. While there were overtly many occasions when didacticians joined teachers in schools, at the invitation of the teachers, and fewer occasions when teachers joined didacticians in planning workshops (it was harder for teachers to take time our from school activity), the more hidden influences are what I address here. As teachers and didacticians interacted, either in workshop or in school, ways of knowing and being together developed. Didacticians gleaned teachers' perceptions of their workshop experiences, and desires for what workshops should offer them. Teachers perceived that didacticians sought not to give didactical instruction but to offer opportunity to engage, and to include teachers in inquiring into possibilities. As a result of such recognitions and perceptions, specific meetings were organized, some called by teachers, some by didacticians, at which views were sought and expressed, and frank exchanges allowed better understandings to grow (Goodchild \& Jaworski, 2005).

\section{ISSUES IN THE PROJECT}

We have seen many positive outcomes from project activity that point to learning and development within the project. However, these matters of learning and development are far from simple and, in the space available here, I focus on some of the issues that have arisen for ongoing thinking and practice.

Hierarchies in mathematics for teaching.

Schools in the project ranged from lower primary to upper secondary. There was thus a wide range of mathematical experience among teachers in the 
project. Teachers with less experience expressed concern when the mathematics discussed seemed to go beyond that with which they were familiar. Conversely teachers at the higher levels wished to work mainly with mathematics at their own level. This meant that teachers overwhelmingly preferred to work with others who taught at the same level as themselves.

Didacticians felt that there was value in working together across school levels in order to develop more understanding of what was experienced by, or expected of students at the different levels. The compromise was usually in favour of same-level groups, although all met together in plenary to share outcomes from group work.

Difficulties with conceptualising inquiry.

Inquiry is a familiar word in the international literature in mathematics education and has represented important concepts within the LCM project as indicated above. Mathematical; tasks in workshops have been inquiry based and a major source of discussion has been what role inquiry-based tasks might play in classrooms. However, there is no one single word in the Norwegian language that can be used to capture the meanings associated with the word "inquiry". Much discussion and debate throughout this project with many groups of people has led to a range of words in Norwegian that can capture the meanings involved. Either because of, or as well as this, it has taken time for the project community as a whole to internalize the meanings of inquiry so that it becomes recognizably a part of practice in a range of levels. During the project, the word inquiry has entered partially into the Norwegian language, so we find the word "inquiry" popping up all the time in Norwegian discussion. How teachers see 
inquiry within their own practice has been central to research. For teachers in upper secondary schools, for example, inquiry tasks have been seen as largely separate from their curriculum-based teaching, so that, for them, day to day teaching cannot be contemplated as being inquiry based.

(Perceived) conflicts with curriculum.

The teachers at higher secondary level experienced a demanding curriculum and indicated that they could not spend time on extra activities. Their perception was that inquiry-based activities would be extra to their curriculum. So, although didacticians worked hard at producing activities which they saw as being clearly curriculum-related, teachers were reluctant to consider using such activities in their classrooms. In one case, teachers in an upper secondary school invited didacticians to work with them to design inquiry-based tasks related to a topic on linear functions. As a result of joint activity, three teachers themselves designed a sequence of four tasks which they each used with pupils, recorded on video by didacticians (Hundeland, Erfjord, Grevholm, \& Breiteig, 2007). In these lessons the teachers reported evidence of a higher level of understanding from their students than they experienced normally. However, time in planning the tasks, and classroom time was greater than normal, and they felt they could not in general afford this amount of time.

\section{Mathematics in the classroom:}

Design of inquiry activity and tasks was focused, directly or indirectly, towards pupils' mathematical development. Teachers took the results of design, from workshops or in schools, into their classrooms and invited didacticians to video- 
record the activity. The video record and emerging analysis points to a broad range of innovative activity and pupils' engagement in inquiry in mathematics. However, analysis has focused on the learning of teachers (and of didacticians) rather than on the learning of pupils per se so we have no measures of pupils' mathematical development over the time of the project. For example, Jørgensen \& Goodchild (2007) report collaboration and learning of a teacher and a didactician in developing activity for first grade pupils. The video data from Jørgensen's classroom shows considerable evidence of pupils' mathematical engagement and exploration, but the paper reports the developing thinking of its authors as they designed, acted in the classroom and reflected on their activity rather than on pupils' learning per se. Similarly, the paper from Hundeland et al (2007), reports from the linear functions activity in upper secondary school. Engagement of pupils in inquiry and discussion was a major feature of this activity, but analysis focuses on task design and learning of teachers and didacticians, rather than the learning per se of the pupils. This is in accord with theoretical perspectives outlined above, particularly addressing questions about the nature of teaching in a community of inquiry.

Tensions for individuals and groups working between project aims and school traditions.

Schools in Norway up to the age of 16 organize pupils in undifferentiated class or year groups. It is illegal to set or stream. Teachers form year teams, so that the teachers working with one year group work and plan together for students in their year. However, the LCM team in a school often crossed several year teams. This made it difficult for teachers in the LCM team to meet each other 
during school hours, and to plan for collaborative work. It was correspondingly difficult for didacticians to meet with a whole school team in school hours. Difficulties in meeting together were given as a reason why some teachers planned and innovated singly with their own class, rather than through working together in their project team.

\section{TENSION AS SOURCE OF LEARNING: EMERGENT VERSUS ESTABLISHED ACTIVITY}

Issues exemplified above have arisen from tensions between the project community and established communities. These tensions can be related to questions of ownership within the project. The project originated through a proposal by didacticians to the research council and became a reality when the research council funded the project. Didacticians designed the project establishing aims and approaches. Thus, workshops, their aims and activity, ideals for school activity etc. were introduced by didacticians. Schools were invited by didacticians and responded voluntarily to participate. Contracts were signed agreeing to certain forms of activity and input (for further detail see Jaworski, 2005). At every stage of the project, didacticians sought the views of teachers and discussed with them where possible the best lines of action. Nevertheless, and unsurprisingly, in the first phase, many teachers gave the impression that they were responding to the wishes of didacticians, and wondering what were the benefits for themselves. In the second phase, when it was clear that teachers' views were sought and workshops planned according to teacher's wishes, some balance was achieved, and in Phase 3 there seemed to be a greater extent of participation by many teachers. Nevertheless, in the 
LCM project, partnership was skewed towards the ideas of didacticians in both design and implementation.

These tensions and their resolution have been important to the project. They have been brought to light by recognition of issues emerging through project implementation. Resolution has often involved compromise with implementations of design and to some extent with the aims of the project. Such compromise has arisen mainly from factors in established communities: for example, the group structure of the school system, perceptions of curriculum demands, or teachers' feelings about mathematical knowledge. In the power imbalance, planning for activity came largely from didacticians and drew on didacticians' knowledge of research literature and theories of learning - part of the established structures of university life. As the project worked through its three phases, forms of practice and ways of dealing with issues and tensions emerged. In terms of a research cycle at the project level, we can see compromises being recognized, reflected on and absorbed into project culture. Both teachers and didacticians were brought up against issues in their own practices and expectations and had to rethink their position, reformulate ideas and reconsider roles within the project (e.g., Cestari, Daland, Eriksen \& Jaworski, 2006; Daland, 2007). This pushed them into a position of addressing aspects of their own familiar practices through new lenses, taking a critical stance and seeking outcomes favourable to their aims within the project. Shifting awareness with respect to such critical alignment can be exemplified by the words of one teacher who, in a focus group interview at the end of Phase 2 spoke as follows: 
Agnes:.... in the beginning I struggled, had a bit of a problem with this because then I thought very much about you should come and tell us how we should run the mathematics teaching. This was how I thought, you are the great teachers. ... but now I see that my view has gradually changed because I see that you are participants in this as much as we are even though it is you that organise. Nevertheless I experience that you are participating and are just as interested as we are to solve the tasks on our level and find possibilities, find tasks, that may be appropriate for the pupils, and that I think is very nice. So I have changed my view during this time. (FG_060313. Translated from the Norwegian by Espen Daland. Daland, 2007)

During the third (and final) phase of LCM, funding was granted for a second project to build on the processes and practices of LCM. The subsequent project, TBM (Teaching Better Mathematics), began with a more equitable balance of power. Both schools and university have their own funding, and activity is planned by a committee representing both partners. This illustrates one important outcome of LCM in organizing developmental research with respect to systemic factors and equity issues.

\section{LEARNING ABOUT TEACHING AND LEARNING - GROWTH AND IDENTITY}

Analysis shows considerable evidence of classroom experimentation, of teachers and didacticians learning from their project activity and of changes in perceptions of what matters for mathematics teaching and learning. A range of publications charts this learning. (http://fag.hia.no/lcm/papers.htm). What this 
means varies for the people involved according to their institutional setting, their own roles within the setting and their responses to the project.

Characterizations have been offered in a book (with some chapters in Norwegian and some in English) which has emerged from the project to which all didacticians and most school teams have contributed (Jaworski et al, 2007). Doctoral students, who at the time of writing this chapter are in the last stages of thesis work, are employed also: in two cases in the university as didacticians, and in one case each in a higher secondary school and in a local professional development team. Three of the original eight schools (primary and lower secondary) are now part of the TBM project, with the upper secondary schools indicating their wish to join. In the TBM project, teachers from LCM schools are taking leadership roles in bringing new schools into developmental activity. Members of the LCM project, didacticians and teachers, at the invitation of the research council, led a national conference to which teachers and didacticians throughout Norway were invited. These events and outcomes show evidence of project-related identity building, both for individuals and groups and associated agency in developmental practice.

\section{REFERENCES}

Brown, S. \& Mclntyre, D. (1993), Making Sense of Teaching. Buckingham: Open University Press.

Cestari, M. L., Daland, E., Eriksen, S., \& Jaworski, B. (2006). Working in a developmental research paradigm: The role of didactician/researcher working with teachers to promote inquiry practices in developing mathematics learning and teaching. In M. Bosch (Ed.), Proceedings of 
the Fourth Congress of the European Society for Research in

Mathematics Education (pp. 1348-1357). Sant Feliu de Guíxols, Spain: Universitat Ramon Llull.

Cochran Smith, M., \& Lytle, S. L. (1999). Relationships of knowledge and practice: Teacher learning in communities. Review of Research in Education, 24, 249-305.

Daland, E. (2007) School teams in mathematics, what are they good for? . In B. Jaworski, A. B. Fuglestad, R. Bjuland, T. Breiteig, S. Goodchild, \& B. Grevholm, (Eds.) Learning Communities in Mathematics. pp. 161-174. Bergen, Norway: Caspar

Goodchild, S., \& Jaworski, B. (2005). Identifying contradictions in a teaching and learning development project. In H. L. Chick \& J. L. Vincent (Eds.), Proceedings of the 29th Conference of the International Group for the Psychology of Mathematics Education (Vol. 3, pp. 41-47). Melbourne, Australia: University of Melbourne.

Hundeland, P. S., Erfjord, I.,Grevholm, B., \& Breiteig, T. (2007). Teachers and researchers inquiring into mathematics teaching and learning: The case of linear functions. In C.Bergsten, B. Grevholm, H. S. Måsøval, \& F. Rønning (Eds.), Relating practice and research in mathematics education. Proceedings of Norma05, Fourth Nordic Conference on Mathematics Education. $(299$ - 310) Trondheim: Tapir Akademisk Forlag.

Jaworski, B. (2003). Research practice into/influencing mathematics teaching and learning development: Towards a theoretical framework based on 
co-learning partnerships, Educational Studies in Mathematics 54, 249282.

Jaworski, B. (2004). Grappling with complexity:.co-learning in inquiry communities in mathematics teaching development.(Invited plenary address.).In M. Johnsen Høines and A. B. Fuglestad, Proceedings of the $28^{\text {th }}$ Conference of the International Group for the Psychology of Mathematics Education (Vol. 1 pp. 17-36). Bergen, Norway:.Bergen University College.

Jaworski, B. (2005). Learning communities in mathematics: Creating an inquiry community between teachers and didacticians. In R. Barwell \& A. Noyes (Eds.), Research in Mathematics Education:.Papers of the British Society for Research into Learning Mathematics, volume 7 (pp. 101-119). London: BSRLM

Jaworski, B. (2006). Theory and practice in mathematics teaching development: Critical inquiry as a mode of learning in teaching, Journal of Mathematics Teacher Education, 9(2), pp.187-211.

Jaworski, B., Fuglestad, A. B., Bjuland, R., Breiteig, T., Goodchild, S., \& Grevholm, B. (Eds.) (2007). Learning Communities in Mathematics. Bergen, Norway: Caspar

Jørgensen, K. O., \& Goodchild, S. (2007). Å utvikle barns forståelse av matematikk. [To develop children's understanding of mathematics] Tangenten, 1/2007. 35-40 \& 49 .

Lave, J. \& Wenger, E. (1991). Situated Learning: Legitimate Peripheral Participation. Cambridge, MA Cambridge University Press. Lave, J.: 1996 'Teaching as Learning, in Practice', in Mind Culture and Activity, 3(3), pp. 149-164. 
Mullis, I. V. S., Martin, M. O., Gonzalez, E. J., \& Chrostowski, S. J. (2004). TIMSS 2003 international mathematics report: Findings from IEA's Trends in International Mathematics and science study at the fourth and eighth grades. Boston MA: TIMSS \& PIRLS International Study Center, Boston College.

Organisation for Economic Co-operation and Development (2004). Learning for tomorrow's world: First results from PISA 2003. Paris: OECD Publications. Retrieved April 4, 2006, from http://www.pisa.oecd.org.htm

Rogoff, B., Matusov, E. and White, C. (1996). Models of Teaching and Learning: Participation in a community of learners. In D. R. Olson and N. Torrance (eds.), The Handbook of Education and Human Development, pp.388-414. Oxford: Blackwell.

Schmittau, J.: 2003: ‘Cultural-Historical Theory and Mathematics Education’, in A. Kozulin, B. Gindis, V. S. Ageyev and S. M. Miller, (eds.), Vygotsky's Educational Theory in Cultural Context, Cambridge University Press, Cambridge, pp.225-245.

Vygotsky, L. (1962). Thought and Language. Cambridge, MA: The MIT Press. Wenger, E.: 1998, Communities of practice, Cambridge University Press, Cambridge.

\footnotetext{
1 The LCM Project was supported within the KUL Programme (Kunskap, Utdanning og Laering Knowledge, Education and Learning) of the Norwegian Research Council (Norges Forskningsraad, NFR). Project number 157949/S20
} 